\title{
Perlindungan Hukum terhadap Konsumen Produk Rekayasa Genetik di Indonesia
}

\author{
Anto Ismu Budianto
}

\begin{abstract}
Genetic engineering as the application of biotechnology can be considered as an advance in the fields of technology and science to satisfy human's needs in farming, health, and industry. A part from pro and contra matters about genetic engineering products concerning whether or not these products are safe for human beings, the most important thing to consider is the legal protection towards people who consume them. The regulation in the forms of Acts concerning the safety of the engineering products seems to be necessary recently, due to the emerging possibilities in the field of human health and environmental care.
\end{abstract}

\section{Pendahuluan}

Menurut perhitungan ahli demografi Perserikatan Bangsa-Bangsa, diperkirakan jumlah penduduk dunia saat ini mencapai kurang lebih enam milyar orang. Dua kali lipat dari jumlah penduduk pada lima puluh tahun yang lalu. Pada lima puluh tahun mendatang, populasi penduduk dunia akan mencapai sembilan milyar.' Dengan populasi penduduk dunia yang cenderung meningkat tersebut akan meningkatkan kebutuhàn pokok manusia di bidang pangan.

Dalam hubungannya dengan usaha manusia untuk mencukupi kebutuhan di bidang pertanian, khususnya pangan, apabila setelah Perang Dunia ke II tidak dilakukan suatu revolusi hijau, maka umat manusia di

"Kartika Adiwilaga. "Isu Keamanan Pangan dan Lingkungan Tanaman Hasil Rekayasa Genetika." Makalah pada Seminar Bioteknologi tentang Kesiapan Indonesia Memasuki Globalisasi Produk Transgenik. Jakarta. 5 September 2000. HIm. 1. 
dunia sekarang ini sudah pasti akan menderita kelaparan. ${ }^{2}$ Di Indonesia, revolusi hijau juga dilakukan dengan menggunakan padi varietas unggul, pengolahan lahan dengan traktor, dan pemrosesan gabah menjadi beras dengan mesin. Dalam perkembangan revolusi hijau lebih lanjut, pemanfaatan benih unggul menjadi semakin mutiak. Pemuliaan benih tidak hanya dilakukan melalui teknik seleksi dan penyilangan, tetapi juga dengan cara antara lain; radiasi dan rekayasa genetik. ${ }^{3}$

Rekayasa genetik secara sederhana dapat didefinisikan sebagai pemindahan materi genetik dari satu spesies ke spesies yang berbeda atau perpindahan gen yang disintesis secara kimiawi ke spesies target. ${ }^{4}$ Di dalam rekayasa genetik, gen-gen diseleksi dan dipindahkan dari suatu organisme ke organisme yang lain, misalnya bakterium bacillus thuringiensis yang memiliki suatu gen untuk memproduksi racun pembunuh serangga. Gen dari bakterium tersebut dimasukkan pada DNA (deoxyribonucleic acid atau asam deoksiribonukleat) ${ }^{5}$ tanaman kapas agar tanaman tersebut dapat membunuh serangga.

Sesungguhnya rekayasa genetik telah digunakan sejak dulu seperti penggunaan ragi untuk mengembangkan roti dan mengubah gula menjadi alkohol dalam pembuatan bir, dan bakteri yang dapat mencerna gula serta menambahkan rasa pada pembuatan keju. Semua teknik rekayasa genetik secara tradisional tersebut menggunakan organisme yang terdapat secara alami. ${ }^{6}$ Rekayasa genetik yang dilakukan sekarang ini, dilakukan oleh para ilmuwan maupun industriawan untuk menciptakan virus, bakteri, ragi, tanaman, maupun binatang yang tadinya tidak pernah ada di alam. Rekayasa genetik yang dilakukan saat ini dilakukan oleh para ahli di bidang bioteknologi untuk kepentingan ilmu pengetahuan dan teknologi maupun untuk kepentingan industri/dagang, di bidang pertanian maupun kesehatan.

Akhir-akhir ini, di beberapa media massa di Indonesia ramai diberitakan mengenai panen raya kapas yang dipetik oleh para petani

${ }^{2}$ Revolusi hijau adalah perubahan pola budi daya tanaman berdasarkan efisiensi. Úntuk itu dilakukan usaha-usaha berupa: 1 . mekanisasi pertanian; 2 . penggunaan benih unggul; 3. penggunaan pupuk dosis tinggi; dan 4. penanggulangan hama/penyakit dengan pestisida. Lihat Rahardi, F. 2000. "Revolusi Hijau vs Pertanian Organik. "Artikel dalam Kontan. No. 25 Tahun IV. 20 Maret 2000. Hlm. 28.

3/bid.

"Lihat: Inez H.S. Loedin. "Transfer Gen Pada Tanaman Dan Aplikasiny." Makalah pada Seminar Bioteknologi tentang Kesiapan Indonesia Memasuki Globalisasi Produk Transgenik. Jakarta. 5 September 2000. Hlm:2.

${ }^{5}$ DNA (deoxyribonucleic acid -asam deoksribonukleat) merupakan bahan dasar sel serta pembawa ciriciri khas suatu organisme. Lihat Kartono.Mohamad. "Simalakama Tanaman Transgenik." Artikel dalam Tempo. 1Oktober 2000. HIm. 97.

${ }^{6}$ Lihat. The Panos Institute. Genetic Engineers Target Third World Crops. Alih bahasa Vinera Zainuddin. KONPHALINDO. 1994. 
kapas di Bantaeng dan Bulukumba, Sulawesi Selatan. ${ }^{7}$ Setelah lima bulan dipelihara di atas lahan seluas 500 hektar, bibit kapas rekayasa genetik (disebut juga kapas transgenik) tersebut bisa dipanen sebanyak tiga kail lipat dari biasanya. Dengan bibit kapas yang secara tradisional biasa ditanam para petani, dari satu hektare tanah biasanya dihasilkan setengah ton kapas, dengan bibit kapas transgenik bisa dipanen kapas sebanyak tiga kali.lipat dari biasanya. Tingkat produktivitas kapas yang luar biasa tersebut pada satu sisi menimbulkan harapan baru bagi keuntungan para petani, mäupun produsen bibit kapas transgenik, namun pada sisi yang lain digunakannya bibit kapas transgenik tersebut dipandang dapat membahayakan alam maupun lingkungan.

Kemajuan ilmu pengetahuan dan. teknologi pada satu sisi membawa manfaat yang, luar biasa bagi umat manusia, namun pada sisi yang lain juga dapat merugikan umat manusia. Persoalannya adalah bagaimana kemajuan ilmu pengetahuan dan teknologi tersebut dapat dimanfaatkan untuk kesejahteraan umat manusia tanpa merugikan bagi manusia itu sendiri maupun terhadap alam. Sebagai salah satu perkembangan ilmu pengetahuan dan teknologi di bidang pertanian maupun kesehatan, rekayasa genetik dianggap sebagai suatu terobosan untuk memenuhi kebutuhan umat manusia yang semakin meningkat. Terlepas dari persoalan pro atau kontra terhadap produk-produk rekayasa genetik, hal yang paling penting adalah bagaimana manusia sebagai konsumen dari produk-produk hasil rekayasa genetik dapat dilindungi secara hukum dari akibat-akibat negatif yang ditimbulkan dari kemajuan ilmu pengetahuan dan téknologi tersebut.

Dalam hubungannya dengan perlindungan hukum terhadap konsumen produk rekayasa genetik, yang mau atau tidak mau maupun suka atau tidak suka produk rekayasa genetik tersebut akan dan bahkan sudah masuk ke Indonesia, apakah perundang-undangan di bidang perlindungan konsumen dapat menjamin konsumen dari akibat-akibat negatif yang ditimbulkan oleh rekayasa genetik.

\section{Rekayasa Genetik}

Rekayasa genetik adalah salah satu aplikasi dari bioteknologi yang merupakan teknologi pemanfaatan organisme (mikroba) atau produk organisme yang bertujuan untuk menghasilkan bahan atau jasa. Bioteknologi bukanlah hal yang baru bagi peradaban manusia, teknologi seperti pembuatan tape, tempe, kecap, dan tuak menunjukkan pemanfaatan mikroba untuk mengubah bahan dasar menjadi bahan yang bersifat ekonomi lebih tinggi. Dari sebab itu bioteknologi dapat dibagi menjadi bioteknologi tradisional dan bioteknologi modern. ${ }^{8}$

${ }^{7}$ Bibit kapas unggul, yang dikenal sebagai kapas transgenik, disuplai oleh anak perusahaan Monsano, salah satu perusahaan multinasional yang berasal dari Amerika Serikat, yaitu PT. Monagro Kimia, kepada para petani di Bantaeng dān Bulukumba, Sulawesi Selatan. Lihat. Agung Rulianto. 'Pertanian Kilat? Nanti Dulu. "Artikel dalam Tempo. 24 September 2000. HIm. 62-63.

'iLihat. Muhammad Djumhana. 1995. Hukum Dalam Perkembangan Bioteknologi. Bandung: PT. Citra Aditya:Bakti. HIm. 37. 
Bioteknologi merupakan penerapan teknologi yang memberikan cara baru untuk memperkuat dan mendukung penelitian biologi lainnya. Bioteknologi juga bukan merupakan teknologi yang muncul begitu saja, tetapi berkembang dari mulai teknologi yang sudah lama mapan dan banyak digunakan oleh para ilmuwan sampai pada penelitian yang lebih strategis, seperti rekayasa genetik pada tanaman maupun hewan. ${ }^{9}$

Dalam sejarah perkembangan ilmu genetika dari mulai Mendel (1865) serta Watson dan Crick (1953) sampai pada kurun waktu tahun tujuh puluhan, telah dihasilkan teknologi baru yang memungkinkan para peneliti mengisolași dan mengidentifikasi DNA; mengidentifikasi, mengisolasi, dan memindahkan gen dari satu organisme ke dalam organisme yang lain. Teknik tersebut dikenal sebagai rekayasa genetik, yaing untuk pertama kalinya diaplikasikan pada penelitian di bidang kedokteran. Rekayasa genetik yang merupakan aplikasi dari bioteknologi modern didasari oleh teknik-teknik baru seperti $\because$ (1) teknologi DNA rekombinan; (2)'-produksi antibodi monoklonal; dan (3) kultur sel dan jaringan. Kombinasi dari ketiga hal tersebut menjádi dasar dari rekayasa genetik untuk tanaman, hewan, maupun mikroba. ${ }^{10} ;$
Organisme yang merupakan produk dari hasil rekayasa genetik, dalam bidang pertanian dikenal sebagai țanaman transgenik, misalnya jagung, kapas, padi, dan sebagainya yang tahan terhadap hama dan herbisida. Di dalam bidang kedokteran, rekayasa genetik digunakan untuk membuat obat dan vaksin, antara lain vaksin hepatitis B. ${ }^{11}$

\section{Aspek Hukum Rekayasa Genetik}

Persoalan kaitan antara hukum dan rekayasa genetik sebagai aplikasi dari bioteknologi, dapat dijelaskan bahwa hukum sebagai kaidah atau norma sosial, tidak terlepas dari nilai-nilai yang berlaku dalam suatu masyarakat. Dapat dikatakan bahwa hukum itu merupakan pencerminan dan konkritisasi dari nilai-nilai yang pada suatu saat berlaku dalam masyarakat. Salah satu fungsi hukum adalah memelihara kemampuan masyarakat untuk menyesuaikan diri dengan kondisi-kondisi kehidupan yang berubah, yaitu dengan cara merumuskan kembali hubunganhubungan esensial antara anggota masyarakat. Dengan perkataan lain, hukum berfungsi dalam memelihara kemampuan masyarakat

${ }^{9}$ Aplikasi dari bioteknologi dapat dilaksanakan pada bidang pertanian, peternaḳan, produksi pangan, medis, pengolahan limbah, produksi enerij, pertambangan, militer, dan industri lainnya. Ibid. HIm. 39-54.

${ }^{10}$ Teknologi DNA rekombinan adalah teknik-teknik untuk rekayasa genetik yang memungkinkan manipulasi DNA sebagai materi genetik utama di dalam sel. Antibodi monoklonal merupakan alą diagnosa spesifik yang memungkinkan deteksi cepat setiap protein yang dihasilkan dalam sel. Kemajuan yang telah dicapai dalam kultur jaringan dan sel memungkinkan perbanyakan cepat dari sel yang direkayasa secara genetik. Lihat. Sugiono Mulyoprawiro. "Kemajuan Riset dan Keșiapan SDM Dalam Pengembangan dan Penerapan Teknologi Transgeni Di Indonesia." Makalah dalam Seminar Bioteknologi tentang Kesiapan Indonesia Memasuki Globalisasi Produk Transgenik. Jakarta. 5 September 2000. Hlm. 1 - 2.

"Lihat Kartono Mohamad. "Simalakama Tanaman Transgenik." Artikel dalam Tempo. 1 Oktober 2000. Him. 97. 
untuk menyesuaikan diri dengan kondisi-kondisi kehidupan yang berubah, dalam hal ini suatu kondisi yang berubah dikarenakan adanya perkembangan dalam bidang bioteknologi.

Rekayasa genetik sebagai salah satu perkembangan dalam bidang bioteknologi merupakan suatu bidang yang berkembang dengan cepat dalam masyarakat dan dapat menimbulkan konflik berupa pro dan kontra tertadap pemanfaatan organisme hasil rekayasa genetik. Dalam kerangka itulah hukum dapat dilihat fungsinya sebagai sarana untuk menyelesaikan konflik yang timbul dalam masyarakat. ${ }^{12}$

Bersamaan dengan kemajuan pesat di bidang bioteknologi, aspek-aspek yang terkait dengan organisme hasil rekayasa genetik, serta keamanannya bagi lingkungan dan kesehatan menjadi topik pembicaraan dan berfungsi sebagai wacana publik pada akhirakhir ini. Pengertian bioteknologi modern (modem biotechnology) terdapat dalam Article 3 sub (i) dari Cartagena Protocol on Bio Safety to the Convention on Biological Diversity yang menyebutkan:

"Modern biotechnology" means the application of :

a. In vitro nucleic acid techniques, including recombinant deoxyribonucleic acid (DNA) and direct injection of nucleic acid into cells or organelles, or b. Fusion of cells beyond the taxonomix family.

Bioteknogi modern, sebagaimana disebutkan di aatas menghasilkan apa yang disebut sebagai LMO (living modified organism) atau sering diterjemahkan sebagai $\mathrm{OHM}$ (organisme hidup yang dimodifikasi). Pengertian dari organisme hidup yang dimodifikasi (untuk selanjutnya disebut OHM) terdapat pada Article 3 sub (g) dari Cartagena Protocol on Biosafety to the Convention on Biological Diversity, yaitu:

"... any living organism that possessor a novel combination of genetic material obtained through the use of modem biotechnology"

Dari pengertian tersebut di atas, dapat diketahui bahwa OHM adalah organisme. hidup $^{13}$ yang memiliki kombinasi bahan genetik baru yang diperoleh melalui aplikasi dari bioteknologi modern, atau secara umum dikatakan sebagai organisme hasil dari rekayasa genetik.

Dalam kaitannya dengan aspek hukum dari rekayasa genetik, aturan yang relevan dengan itu adalah Cartagena Protocol on Biosafety to the Convention on Biological Diversity. Protokol tersebut merupakan aturan yang melengkapi Konvensi Perserikatan Bangsa-Bangsa Tentang Keanekaragaman

${ }^{12}$ Satjipto Rahardjo. 1986. Ilmu Hukum. Bandung: Penerbit Alumni. Him 24-61.

${ }^{13} \mathrm{Adapun}$ yang dimaksud dengan organisme hidup (iving organism), disebutkan dalam Article $3 \mathrm{sub}$ (h) Cartagena Protocol on Biosafety to the Convention on Biological Diversity, yakni sebagai berikut:

" ... any biological entity capable of transferring or replicating genetic material. Including sterile organism, viruses and viroids" 
Hayati 1992 (Convention on Bioligical Diversity). Konvensi ini merupakañ salah satú hasil dari diseleniggarakannya United Nations Conference on Environment and Development (UNCED) ${ }^{14}$ dari tanggal 3 sampai 14 Juni 1992. Konvensi ini telah ditandatangani oleh 157 negara, dan Indonesia merupakan negara yang kedelapan yang menandatangani konvensi tersebut di Rio de Janeiro; pada tanggal 5 Juni 1992. Selanjutnya Konvensi Keanekaragaman Hayati diratifikasi oleh Indonesia melalui Undang-Undang Nomor 5 Tahun 1994 tentang Pengesahan United Nations on Biological Diversity (Konvensi Perserikatan Bangsa-Bangsa mengenai Keanekaragaman Hayati).

Tujuan dibuatnya Konvensi Keanekaragam hayati adalah sebagai berikut: ${ }^{15}$ ".

Konservasi keanekaragaman, hayati, pemanfaatan komponen-komponennya secara berkelanjutan dan membagi keuntungan yang dihasilkan dari pendayagunaan sumber daya genetik secara adil dan merata, termasuk melalui akses yang memadai terhadap sumber daya genetika dan dengan alih teknologi yang tepat guna, dan dengan memperhatikan semua hak atas sumbersumber daya dan teknologi itu, maupun dengan pendanaan yang memadai" .
- Hal yang:terkait dengan rekayasa genetik didapatkan dalam ketentuan Pasal 2 Konvensi Keanekaragaman Hayati, yaitu:

"penerapan teknologi yang menggunakan sistem-sistem hayati, makhluk hidup atau derivatifnya, untuk membuat atau memodifikasi produk-produk atau prosesproses untuk penggunaan khusus" (kursif penulis)

Persoalan rekayasa genetik yang terkait dengan kesehatan manusia, terdapat däam Konvensi Keanekaragaman Hayati dan diatur dalam Pasal 8 sub (g) yang mengatakan:

"mengembangkan atau memelihara caracara untuk mengatur, mengelola atau 'mengendalikan risiko yang berkaitan dengan penggunaan dan pelepasan organisme termodifikasi hasil bioteknologi, yang mungkin mempunyai dampak lingkungan merugikan yang dapat mempengaruhi konservasi . dan pemanfaatan secara berkelanjutan keanekaragaman hayati, dengan memperhatikan pula risiko terhadap kesehatan manusia" (kursif penulis)

Pasal 19 tentang Penanganan Bioteknologi dan Pembagian Keuntungan pada' ayat (4) menyebutkan:

${ }^{14}$ United Nations Conference on Environment and Development (UNCED) 1992 (KTT Bumi), menghasilkan: Deklarasi Rio tentang Pembangunan dan Lingkungan, Agenda 21: Program Kerja Aksi PBB dari Rio; (ketiga), Pernyataan tentang Prinsip-Prinsip Kehutanan, Konvensi tentäng Perubahan IKlim, Konvensi tentang Keanekaragaman Hayati.

${ }^{15}$ Pasal 1 Undang-Undang Nomor 5 tahun 1994 tentang Pengesahan United Nations on Biological Diversity (Konvensi Perserikatan Bangsa-Bangsa tentang Keanekaragaman Hayati). 
"Setiap pihak yang secara langsung atau dengan melalui pejabat resmi menurut yurisdiksinya menyediakan organisme termodifikasi hasil bioteknologi, harus menyediakan informasi yang ada tentang peraturan penggunaan dan keamanan yang.diperlukan oleh Pihak tersebut dalam menangani organisme semacam itu, maupun informasi yang ada mengenai dampak potensial organisme tertentu kepada Pihak yang akan menerima organisme tersebuf'. (kursif penulis)

Mengingat hal-hal tersebut di atas, maka dibuatlah Cartagena Protocol On Biosafety to the Convention on Biological Diversity, sebagaimana disebutkan pada Pasal 19 ayat (3) Konvensi Perserikatan Bangsa-Bangsa Tentang Keanekaragam Hayati, yakni:

"Para Pihak wajib mempertimbangkan kebutuhan akan protokol dan modelmodelnya yang menentukan prosedur yang sesuai, mencakup, khususnya persetujuan yang diinformasikan lebih dulu, di bidang pengalihan, penanganan, dan pemanfaatan secara aman terhadap organisme termodifikasi hasil bioteknologi, yang mungkin mempunyai akibat merugikan terhadap konservasi dan pemanfaatan secara berkelanjutan keanekaragaman hayati". (kursif penulis)

Cartagena Protocol on Biosafety to the Convention on Biological Diversity, untuk selanjutnya disebut Cartagena Protocol, dibuat dengan tujuan untuk:

"... in accordance with the precautionary approach contained in Principle 15 of the Rio Declaration on Environment and Development, the objective of this Protocol is to contribute to ensuring an adequate level of protection in the field of the safe transfer, handling and use of living modified organism resulting from biotechnology that may have adverse effects on the conservation and sustainable use of biological diversity, taking also into account risks to human health, and specifically focusing on -transboundary movements". (kursif penulis)

Cartagena Protocol tersebut merupakan tindak lanjut dari persoalan keamanan pangan dalam Konvensi Perserikatan Bangsa-Bangsa tentang Keamanan Hayati.

Persoalan yang paling penting berkaitan dengan $\mathrm{OHM}$ yang merupakan produk dari rekayasa genetik adalah risiko yang berkaitan dengan kesehatan manusia, sehingga pemanfaatan dari produk hasil rekayasa genetik perlu dilaksanakan dengan prinsip kehati-hatian (precautionary principle). Untuk itulah perundang-undangan yang harus mengakomodasikan semua kepentingan para pihak yang terkait dengan rekayasa genetik menjadi hal yang sangat perlu untuk ditindaklanjuti.

\section{Produk Rekayasa Genetik yang Berkembang pada Saat Ini}

Organisme hidup yang dimodifikasi (OHM) merupakan produk dari rekayasa genetik yang berkembang pesat akhir-akhir ini, baik dalam bidang kedokteran maupun pertanian. Sebagaimana telah disebutkan dimuka, OHM secara tradisional sudah dikenal pada jaman dahulu dalam bentuk pembuatan bir, tape, tempe, dan lain-lain namun seiring dengan perkembangan di 
bidang ilmu pengetahuan dan teknologi, produk rekayasa genetik menjadi semakin beragam. Dalam bidang kedokteran, kontroversi produk rekayasa genetik relatif tidak menimbulkan pro dan kontra, kecuali organ-organ dari tubuh babi transgenik yang diperlukan untuk menggantikan organ-organ tubuh manusia yang rusak. Berbeda halnya dengan produk rekayasa genetik yang digunakan dalam bidang kedokteran, produk rekayasa genetik yang digunakan dalam bidang pertanian lebih menimbulkan kontroversi antara satu pihak yang pro dan pihak lain yang kontra. Kontroversi yang muncul adalah mengenai aman atau tidaknya tanaman transgenik itu dengan alam, serta aman atau tidaknya hasil dari tanaman transgenik tersebut untuk dikonsumsi oleh manusia. Persoalan itulah sangat menarik untuk dicermati.

Dalam bidang pertanian, rekayasa genetik oleh beberapa kalangan diartikan sebagai alternatif untuk memenuhi kebutuhan akan pangan yang semakin meningkat, sementara pada pihak yang lain hasil rekayasa genetik berupa tanaman transgenik merupakan komoditas yang menguntungkan secara komersial, maupun organisme bukan dari alam yang masih diragukan efektivitasnya untuk mereduksi hama maupun penyakit tanaman. Dalam beberapa dekade akhir-akhir ini beberapa negara di dunia sudah sejak beberapa tahun yang lalu mengembangkan tanaman transgenik. ${ }^{16}$ Dikawasan Asia, negara India, Cina, dan Korea menjadi pengembang utama dari tanaman transgenik, sementara itu Amerika Serikat tercatat sebagai negara yang menguasai produk tanaman transgenik.

Pengembangan tanaman transgenik di Indonesia dimulai sejak tahun 1985 dengan dibentuknya Panitia Nasional Bioteknologi di bawah Menteri Negara Riset dan Teknologi. Dalam perkembangan lebih lanjut kegiatan penelitian rekayasa genetik pada tanaman untuk menghasilkan tanaman transgenik telah dilakukan di berbagai lembaga penelitian, yakni: ${ }^{17}$

${ }^{18}$ Selama -kurun waktu 1996 - 1998, secara global areal penanaman tanaman transgenik meningkat sepuluh kali lipat, dari 1,7 juta hektar menjadi 20,8 juta hektar. Bahkan tahun 2000 diperkirakan akan mencapai 60 juta hektar. Lihat "Padi Transgenik, Harapan di Tengah Kontroversi." Artikel dalam Kompas. 17 September 2000.

${ }^{17}$ Sugiono Moeljopawiro. "Kemajuan Riset dan Kesiapan SDM Dalam Pengembangan Dan Penerapan Teknologi Transgeni di Indonesia." Makalah dalam Seminar tentang Kesiapan Indonesia memasuki Globalisasi Produk Transgenik. 5 September 2000. HIm 4 - 5. 


\begin{tabular}{|l|l|l|l|l|}
\hline No & \multicolumn{1}{|c|}{ Tanaman } & \multicolumn{1}{|c|}{ Sifat } & \multicolumn{1}{c|}{ Gen Instansi } \\
\hline 1 & Jagung & Tahan penggerekbatang & Pin II & Balitbio \\
\hline 2 & Kacangtanah & Tahan Pstv & CP & Balitbio dan IPB \\
\hline 3 & Kakao & Tahan penggerek buah & Bt & UPBP \\
\hline 4 & Kedelai & Tahan penggerekpolong & Pin II. & Balitbio \\
\hline 5 & Padi & $\begin{array}{l}\text { Tahanpenggerekbatang } \\
\text { Tahanpenggerekbatang } \\
\text { dan wereng coklat }\end{array}$ & Bt & Balitbio \\
\hline 6 & Papaya & Tahan PRS & Bt \& GNA & P3B LIPI \\
\hline 7 & Tebu & Tahan penggerekbaiang & BP & Balitbio, Balitsa, Balitbu \\
\hline 8 & Tembakau & Tahan TMV & CP & P3GI \\
\hline 9 & Ubi jalar & Tahanhamaboleng & Pin II & Balititbio \\
\hline
\end{tabular}

Sementara itu melalui kerjasama dengan lembaga penelitian di luar negeri, juga sudah dihasilkan beberapa tanaman transgenik, seperti:

\begin{tabular}{|l|l|l|l|l|}
\hline No & \multicolumn{1}{|c|}{ Tanaman } & \multicolumn{1}{|c|}{ Sifat } & Gen & \multicolumn{1}{|c|}{ Instansi } \\
\hline 1 & Jagung & Tahan penggerek batang & Bt & Balitbio/CCI Seed Co \\
\hline 2 & Kacang tanah & Tahan Pstv & $\mathrm{CP}$ & Balitbio/ACIAR \\
\hline 3 & Kentang & Tahan PTM & Bt & Balitbio/MSU \\
\hline 4 & Ubi jalar & Tahan SPFMV & $\mathrm{CP}$ & Balitbio/Monsanto \\
\hline
\end{tabular}

Terhadap pengembangan tanaman transgenik di Indonesia, sesungguhnya sudah ada pengaturan hukumnya, yakni melalui SK Menteri Pertanian Nomor 856/Kpts/HK.330/9/ 1997 tentang Pelepasan Tanaman Transgenik. Aturan inilah yang diikuti oleh semua pihak yang terkait dengan pengembangan tanaman transgenik, baik untuk kepentingan riset maupun komersial. Prosedur yang ditetapkan dalam surat keputusan tersebut adalah mulai dari uji rumah kaca selama tiga bulan, uji lapangan terbatas selama enam bulan, sampai akhirnya mendapatkan sertifikat "aman hayati". Selain surat keputusan dari menteri pertanian tersebut, Pemerintah sudah menerbitkan pula Surat Keputusan Bersama (SKB) untuk mengatur masalah Keamanan Hayati dan Keamanan Pangan Produk Pertanian Hasil Rekayasa Genetika pada bulan September 2000. Aturan itu tertuang dalam empat buah SKB yang ditandatangani Menteri Pertanian, 
Menteri Kehutanan dan Perkebunan, Menteri Kesehatan, dan Menteri Negara Pangan dan Holtikultura.
Adapun data yang dapat disajikan mengenai tanaman transgenik yang telah ditanam di Indonesia adälah sebagai berikut: ${ }^{18}$

\begin{tabular}{|c|c|c|c|c|c|c|}
\hline No & Tanaman & Gen & Sifat & Perusahaan & Lokasi & Luas \\
\hline 1 & Jagung & Cry I ab & Tahan penggerekbatang & Monago & Jawa Tengah & - \\
\hline 2 & Jagung & Cry I ab & Tahan penggerek batang & Pioneer & - & - \\
\hline 3 & Jagung & EPSPS & Herḅisidaglisofat & Monagro & Jawa Tengah & - \\
\hline 4 & Jagung' & Pin II & Tahan penggerek batang & Balitbio & - & - \\
\hline 5 & Kapas & $\mathrm{Cry} / \mathrm{ab}$ & Tahan penggerek bunga & Monagro & Sulsel & 500 ha \\
\hline 6 & Kapas & EPSPS & Tahan herbisidaglisofat & Monagro & Jawa Tengah & \\
\hline 7 & Kedelai & EPSPS & Tahan herbisidaglisofat & Monagro & Jawa Tengah & \\
\hline 8 & Kentang. & Cry V & Tahan penggerek daun dan ubi & Balitbio & - & \\
\hline 9 & Padi & Cry l ab & Tahan penggerek batang & Balitbio & - & - \\
\hline 10 & Padi & $\begin{array}{l}\text { Cry I ab } \\
\text { dan GNA }\end{array}$ & $\begin{array}{l}\text { Tahan penggerek batang dan } \\
\text { wereng coklat }\end{array}$ & LIPI' & - & - \\
\hline
\end{tabular}

\section{Perlindungan Hukum terhadap}

\section{Konsumen Produk Rekayasa Genetik}

Dilepaskannya tanaman produk rekayasa genetik ke alam dipandang memiliki risiko terhadap lingkungan dan kesehatan manusia. Beberapa kemungkinan yang dapat terjadi misalnya tanaman transgenik berubah menjadi gulma, terjadinya perpindahan gen di spesies lain yang berakibat buruk, dan risiko terhadap kesehatan karena digunakannya tanaman transgenik sebagai makanan. ${ }^{19}$ Dalam kaitannya dengan perlindungan hukum terhadap konsumen produk rekayasa genetik, kepentingan konsumen.yang perlu dilindungi adalah keamanan terhadap kesehatan apabila mengkonsumsi produk rekayasa genetik.

${ }^{18}$ Kompas. 2 November 2000.

${ }^{19} \mathrm{Kartika}$ Adiwilaga. Op. Cit. HIm. 3. 
Produk tanaman transgenik ternyata ada yang memiliki kemungkinan menimbulkan efek samping yang merugikan, antara lain dapat mengganggu metabolisme tubuh sehingga menimbulkan penyakit dan menimbulkan alergi, misalnya jagung $\mathrm{BT}$ cry $9 \mathrm{c}$ yang diduga bisa menimbulkan efek alergi bila dikonsumsi manusia. Hal itu dapat terjadi karena dalam pengujian di laboratorium yang dilakukan oleh Food and Drug Agency (FDA) terbukti bahwa protein di jagung jenis $B T$ cry $9 \mathrm{c}$ belum terdegradasi meskipun telah dipanaskan dalam waktu setengah jam. Ikatan molekul protein ini lebih kuat dan mirip dengan unsur yang dapat memuncuikan alergi pada tubuh manusia. Apabila jagung BT $\mathrm{cry} 9 \mathrm{c}$ ini dikonsumsi manusia, maka dapat menimbulkan reaksi shock di tubuh dan mual, terlebih lagi apabila dikonsumsi oleh orang yang alergen, sehingga dapat menimbulkan reaksi keras sampai menimbulkan hal yang fatal. ${ }^{20}$

Dalam hubungannya dengan perlindungan konsumen, Resolusi PBB Nomor 39/248 Tahun 1985 tentang Perlindungan Konsumen (Guidelines for Consumer Protection), merumuskan berbagai kepentingan konsumen yang perlu dilindungi, yakni:

a) perlindungan konsumen dari bahayabahaya terhadap kesehatan dan keamanannya;

b) promosi dan perlindungan kepentingan ekonomi sosial konsumen;

c) tersedianya informasi yang memadai bagi konsumen untuk memberikan kemampuan mereka melakukan pilihan yang tepat sesuai kehendak dan kebutuhan pribadi;

d) pendidikan konsumen;

e) tersedianya upaya ganti rugi yang efektif; f) kebebasan untuk membentuk organisasi konsumen atau organisasi lainnya yang relevan dan memberikan kesempatan kepada organisasi tersebut untuk menyuarakan pendapatnya dalam proses pengambilan keputusan yang menyangkut kepentingan mereka.

Dari resolusi tersebut, unsur perlindungan konsumen dari bahaya-bahaya terhadap kesehatan dan keamanannya menduduki prioritas yang pertama. Selanjutnya adalah bagaimana halnya dengan perlindungan konsumen yang ada di Indonesia.

Pengaturan secara khusus terhadap perlindungan konsumen produk rekayasa genetik sampai saat ini belum ada di Indonesia, namun secara umum perlindungan hukum terhadap konsumen di Indonesia sudah diatur dalam Undang-Undang Nomor 8 Tahun 1999 tentang Perlindungan Konsumen (untuk selanjutnya disebut Undang-Undang Perlindungan Konsumen). Adapun yang dimaksud dengan perlindungan konsumen di dalam undang-undang adalah "segala upaya yang menjamin adanya kepastian hukum untuk memberikan perlindungan kepada konsumen" (kursif penulis).

Konsumen itu sendiri menurut UndangUndang Perlindungan Konsumen adalah "setiap orang pemakai barang dan/atau jasa yang tersedia dalam masyarakat, baik bagi

${ }^{20}$ Kompas. 4 November 2000. 
kepentingan diri sendiri, keluarga, orang lain maupun makhluk hidup lain dan tidak untuk diperdagangkan" (kursif penulis). Maksud dari perkataan tidak untuk diperdagangkan yang dinyatakan dalam definisi konsumen di atas sejalan dengan pengertian pelaku usaha yang dimaksudkan dalam undang-undang, yakni:

"setiap perorangan atau badan usaha, baik yang berbentuk badan hukum maupun bukan badan hukum yang didirikan dan berkedudukan atau melakukan kegiatan dalam wilayah hukum negara Republik Indonesia, baik sendiri maupun bersama-sama melalui perjanjian menyelenggarakan kegiatan usaha dalam berbagai bidang ekonomi".

Dari ketentuan tersebut di atas dan apabila dihubungkan dengan produk tanaman transgenik, maka tidak hanya produsen tanaman transgenik saja yang tunduk pada undang-undang ini, melainkan para rekanan, agen, distributor, serta jaringan-jaringan yang melaksanakan fungsi pendistribusian dan pemasaran barang dan/atau jasa.kepada masyarakat luas selaku pemakai dan/atau pengguna barang dan/atau jasa harus tunduk pada ketentuan perundang-undang tentang perlindungan konsumen. Tampaknya Undang-Undang Perlindungan Konsumen di . Indonesia ditujukan untuk melindungi kepentingan konsumen, dan bukan hanya melindungi kepentingan pelaku usaha untuk kepentingan mereka sendiri. ${ }^{21}$

Sepanjang berhubungan dengan produk tanaman trasgenik yang dapat merugikan konsumen, maka pihak-pihak terkait yang bertanggung jawab adalah tidak hanya produsen saja, melainkan sampai kepada rekanan, agen, distributor, serta jaringanjaringan yang melaksanakan fungsi pendistribusian dan pemasaran produk rekayasa genetik. Selanjutnya UndangUndang Perlindungan Konsumen mengatur secara jelas masing-masing hak dan kewajiban konsumen maupun hak dan kewajiban pelaku usaha. Sampai sejauh mana hak dan kewajiban itu dapat diimplementasikan terhadap produk rekayasa genetik, hal itu masih perlu dikaji dengan seksama.

Konsumen yang ada di Indonesia jumlahnya saat ini diperkirakan 120 juta orang, berdasarkan ketentuan Undang-Undang Perlindungan Konsumen, hak-hak konsumen adalah:

1. hak atas kenyamanan, keamanan, dan keselamatan dalam mengkọnsumsi barang/jasa;

2. hak untuk memilih barang/jasa sesuai dengan nilai tukar dan kondisi, serta. jaminan yang diberikan;

3. hak atas informasi yang benar, jelas, dan jujur mengenai kondisi dan jaminan barang/jasa;

4. hak untuk didengar péndapat "dan keluhannya atas barang/jasa yang digunakan;

5. hak untuk mendapatkan advokasi, perlindungan dan upaya penyelesaian sengketa perlindungan konsumen secara patut;

${ }^{2 t}$ Gunawan Widjaja dan Ahmad Yani: 2000. Hukum Tentang Perlindungan Konsumen. Jakarta: PT. - Gramedia Pustaka Utama. HIm:4-10. 
6. hak untuk mendapatkan pembinaan dan pendidikan konsumen;

7. hak untuk diperlakukan atau dilayani secara benar dan jujur serta tidak diskriminatif;

8. hak untuk mendapatkan kompensasi, ganti rugi/penggantian, jika barang/jasa yang diterima tidak sesuai dengan perjanjian atau tidak sebagaimana mestinya;

9. hak yang diatur dalam peraturan perundangan lainnya

Kesembilan hak konsumen tersebut di atas, dimiliki oleh konsumen yang memanfaatkan produk tanaman transgenik. $\mathrm{Di}$ samping itu beberapa hal penting yang harus. dipahami dan merupakan pengaturan yang relatif baru dalam sistem hukum dan perundangan di indonesia, khususnya perlindungan terhadap konsumen, adalah mengena:

1. klausula baku;

2. pembuktian terbalik;

3. class action;

4. Badan Perlindungan Konsumen Nasional (BPKN); dan

5. Badan Penyelesaian Sengketa Konsumen (BPSK).

Persoalannya adalah apakah semua itu sudah dianggap mencukupi untuk melindungi konsumen dari pengaruh-pengaruh negatif yang ditimbulkan oleh produk rekayasa genetik. Hal yang lebih penting pada saat ini adalah pendekatan kehati-hatian untuk mencermati segala kemungkinan yang dapat ditimbulkan oleh produk rekayasa genetik dari sisi keamanannya untuk dikonsumsi.

Untuk menjamin keamanan produk hasil rekayasa genetik terhadap lingkungan maupun terhadap kesehatan, sudah selayaknya apabila produk-produk rekayasa genetik tersebut melewati proses pengujian sebelum dipasarkan kepada konsumen. Metode pengujian keamanan produk maupun penelitian atas tanaman transgenik harus sesuai dengan standar yang ditentukan oleh badan-badan pengawas kesehatan dan pangan dunia, seperti WHO maupun FAO, sehingga dapat dijamin bahwa produk rekayasa genetik tersebut aman untuk dikonsumsi. Di samping itu, terhadap produk rekayasa genetik yang sudah dipasarkan dan dikonsumsi oleh masyarakat perlu diberikan labelisasi maupun rekomendasi terhadap tingkat keamanannya untuk dikonsumsi, sehingga konsumen dapat menentukan pilihan, apakah akan mengkonsumsi produk rekayasa genetik atau tidak.

Hal yang lebih utama dari perlindungan hukum terhadap konsumen produk rekayasa genetik, selain implementasi dari perundangundang di bidang perlindungan konsumen, adalah menyiapkan perangkat lunak, berupa peraturan yang mewajibkan untuk menguji tingkat keamanan produk rekayasa genetik dari tingkat hulu sampai hilir, maupun perangkat kerasnya, berupa lembagalembaga penilai ataupun laboratorium yang secara ilmiah dapat membuktikan tingkat keamanan produk rekayasa genetik untuk dapat dikonsumsi secara aman oleh manusia.

\section{Simpulan}

Perkembangan ilmu pengetahuan dibidang bioteknologi tidak dapat dihambat karena adanya kontroversi aman atau tidaknya produk rekayasa genetik. Sudah selayaknya apabila aplikasi dari bioteknologi dalam bentuk rekayasa genetik digunakan untuk 
memenuhi kebutuhan umat manusia. di bidang kesehatan, pertanian, peternakan, maupun industri. Meskipun rekayasa genetik digunakan sebagai terobosan di bidang kesehatan maupun pertanian untuk memenuhi kebutuhan umat manusia yang semakin meningkat, dan terlepas dari pengaruh positip maupun negatifnya produk rekayasa genetik, sikap kehati-hatian sangatlah diperlukan untuk mencermati segala kemungkinan yang dapat terjadi pada konsumen produk rekayasa genetik.

Sosialisasi aman atau tidaknya produk rekayasa genetik akan sangat membantu pemahaman konsumen untuk dapat menentukan pilihannya untuk mengkonsumsi atau tidak mengkonsumsi produk rekayasa genetik, yang saat sekarang ini sudah beredar secara luas. Labelisasi produk rekayasa genetik akan membantu konsumen untuk dapat menentukan pilihannya. Tidak kalah pentingnya adalah implementasi dari peraturan yang sudah ada untuk melindungi tidak hanya konsumen produk rekayasa genetik, tetapi juga pelaku usaha dari produk rekayasa genetik. $\square$

\section{Daftar Pustaka}

Adiwilaga, Kartika. "Isu Keamanan Pangan dan Lingkungan Tanaman Hasil Rekayasa Genetika". Makalah pada Seminar Bioteknologi tentang Kesiapan Indonesia Memasuki Globalisasi Produk Transgenik. Jakarta. 5 September 2000

Djumhana, Muhammad. 1995. Hukum Dalam Perkembangan Bioteknologi. Bandung: Penerbit PT. Citra Aditya Bakti.
Institute, The Panos. 1994. Genetic Engineers Target Third World Crops. Alih bahasa Vinera Zainuddin. KONPHALINDO.

Loedin, Inez H.S. "Transfer Gen Pada Tanaman Dan Aplikasinya." Makalah pada Seminar Bioteknologi tentang Kesiapan Indonesia Memasuki Globalisasi Produk Transgenik. Jakarta. 5 September 2000

Mohamad, Kartono. "Simalakama Tanaman Transgenik." Artikel dalam Tempo. 1 Oktober 2000.

Rahardi, F. "Revolusi Hijau vs Pertanian Organik". Artikel dalam Kontan. №. 25 Tahun IV, 20 Maret 2000.

Rahardjo, Satjipto. 1986. Ilmu Hukum. Bandung: Penerbit Alumni.

Rulianto, Agung. "Pertanian Kilat? Nanti Dulu." Artikel dalam Tempo. 24 September 2000

Widjaja, Gunawan dan Ahmad Yani. 2000. Hukum Tentang Perlindungan Konsumen. Jakarta: PT. Gramedia Pustaka Utama.

Kompas. 17 September 2000

- 2 November 2000 4 November 2000.

Kontan. No. 25 Tahun IV, 20 Maret 2000

Tempo. 1 Oktober 2000 , 24 September 2000.

United Nations Convention on Biological Diversity 1992 
Undang-Undang Nomor 5 tahun 1994 tentang Undang-Undang Nomor 8 Tahun 1999 Pengesahan United Nations on Biologitentang Perlindungan Konsumen.

cal Diversity (Konvensi Perserikatan

Bangsa-Bangsa tentang Keanekaragaman Hayati).

2 